\title{
AVAILABLE SOIL PHOSPHORUS IN COCONUT PLANTATIONS IN BORALU AND PALLAMA SOIL SERIES, UNDER DIFFERENT FERTILIZER REGIMES, IN GAMPAHA DISTRICT OF SRI LANKA.
}

\author{
J.A.D.S.S.Jayakody ${ }^{1}$, N.A.Tennakoon ${ }^{2}$ and M.N.D.Fernandopulle ${ }^{1}$ \\ ${ }^{1}$ Department of Plantation Management,Faculty of Agriculture and \\ Plantation Management, Wayamba University of Sri Lanka, Makandura, \\ Gonawila (NWP); ${ }^{2}$ Soils and Plant Nutrition Division,Coconut Research \\ Institute, Lunuwila, Sri Lanka.
}

\begin{abstract}
Coconut plantations in the Gampaha District of Sri Lanka are generally under fertilized or not fertilized at all. The available soil phosphorus in the two major coconut growing soils in the district viz. Boralu and Pallama series, under three fertilizer regimes, organic manures, inorganic fertilizers, or no fertilizer, over the preceding five-year period, was determined and mapped. Some 32,400 ha were covered with 30 sampling locations. Leaf $\mathrm{P}$ content was also determined at selected sampling locations.

Available $\mathrm{P}$ in the Boralu and Pallama soils was at a 'medium' level of sufficiency, with a mean of $16 \mathrm{mg} / \mathrm{kg}$, even in unfertilized coconut plantations. Leaf-P concentration in all the coconut plantations fertilized annually with inorganics, ranging from 0.135 to $0.196 \%$, were higher than the critical leaf-P concentration $(0.120 \%)$. These findings show that the available phosphorus in the two major soil series in the Gampaha District, were generally sufficient to support a healthy growth of coconut.
\end{abstract}

Key Words: Available phosphorus, Boralu soil series, Coconut, Fertilizer, Pallama soil series.

\section{INTRODUCTION}

Coconut (Cocos nucifera.L) is of great economic importance in Sri Lanka; it contributes $2.0 \%$ of the Gross Domestic Product (GDP) and earns around SLR 9,000 million, in foreign exchange, annually (Anon ${ }^{\mathrm{a}}$, 2003). The main coconut growing area of Sri Lanka, referred to as the Coconut Triangle, is comprised of Kurunegala \& Puttalam Districts of the North Western Province, and Gampaha District of the Western Province. The Coconut Triangle contains $61 \%$ of the land monocropped in coconut, with the Gampaha District accounting for 8\% (Anon' ${ }^{\mathrm{b}}$ 2003). 
Phosphorus is an important nutrient for both immature and mature coconut. Phosphorus increases leaf production, girth at collar and root density of coconut seedlings; and increases leaf production, lowers the age of flowering and reduces the incidence of leaf disease caused by the fungus Helminthosporium incurvatum in young palms (Loganathan et. at., 1984). In mature palms, experiments at Madampe, Veyangoda, Ahangama, Bandirippuwa, Pothukulama and Bingiriya in Sri Lanka showed spectacular yield responses to application of phosphorus (Loganathan et. al., 1984). It appears that consistent, significant effects on nut and copra yields to the application of phosphorus fertilizer have not been demonstrated in other countries (Loganathan et.al., 1984).

The coconut growing soils in Sri Lanka are generally deficient in total as well as the active and available forms of phosphorus. Although soils of the Ultisols had marginal to moderate amounts of total phosphorus, the active and available fractions were extremely low (Loganathan et. al., 1983). Leaf analytical data from the joint FAO/CRI/CCB study to increase yields in small holdings through the use of fertilizers revealed that about $85-90 \%$ of the holdings have adequate levels or an excess of phosphorus. Accordingly, phosphorus is placed fourth in the order of priority of nutrients for adult coconut in Sri Lanka; (Anon, 1989).

The objective of the present study is to determine the amounts of available phosphorus in the two major coconut growing soils of Gampaha District namely, Boralu and Pallama series, and map the available phosphorus in this area. Plantations which have a history of (a) not been fertilized (b) fertilized with organic manures and (c) fertilized with inorganic fertilizers will be sampled for this purpose. This information on available phosphorus is expected to provide a rough estimate of the phosphorus fertilizer requirements of coconut as well as the associated intercrops. Variation of available phosphorus, extracted by Bray and Kurtz No.1 method, with different fertilizer management practices, the P-nutritional status of the palms, and the relationship between leaf $\mathrm{P}$ and available soil phosphorus will also be studied.

\section{MATERIALS AND METHODS}

The study was conducted, from December 2004 to June 2005, in the Soils and Plant Nutrition Division of the Coconut Research Institute, Lunuwila, Sri Lanka. 


\section{Collection of Soil Samples}

Boralu and Pallama soil series of the Red Yellow Podzolic soils in the WL3 agro-ecological region of the Gampaha District cover an extent of 32,400 ha. This area was sampled at the rate of one sampling location per 270 ha. as shown in Figure 1. Altogether 120 soil samples were collected from both soil series at 30 locations. They were comprised of 40 soil samples each, from coconut lands that at least during the preceding five years, were (a) not fertilized (b) fertilized annually with organic manure (Cattle manure + APM or Poultry manure + APM or Leaf litter + APM) and (c) fertilized annually with inorganic fertilizer (APM). APM is the Adult Palm Mixture recommended by CRI.

Four composite soil samples were collected for analysis from each of the 30 sampling locations: top soil and subsoil of the manure circle (MC) and the coconut square (CS). At each sampling location, soil samples were drawn from the manure circles of four palms; at four points in each manure circle, and at two depths (0-25 cm-top soil and 25-50 cm-subsoil). The soils taken from each depth were bulked separately to give two composite samples to represent the manure circle (MC). Another set of soil samples were drawn from the centres of four coconut squares, at two depths $(0-25 \mathrm{~cm}$-top soil and 25-50 cm-subsoil) and bulked as before, to give two composite samples to represent the coconut square (CS) or the natural soil of the location.

The soil samples were air-dried $\left(25-30^{\circ} \mathrm{C}\right.$ for $3-5$ days) in the laboratory, ground with a wooden pestle, passed through a $2 \mathrm{~mm}$ sieve and stored for chemical analysis ( $\mathrm{pH}$, electrical conductivity and available phosphorus). 


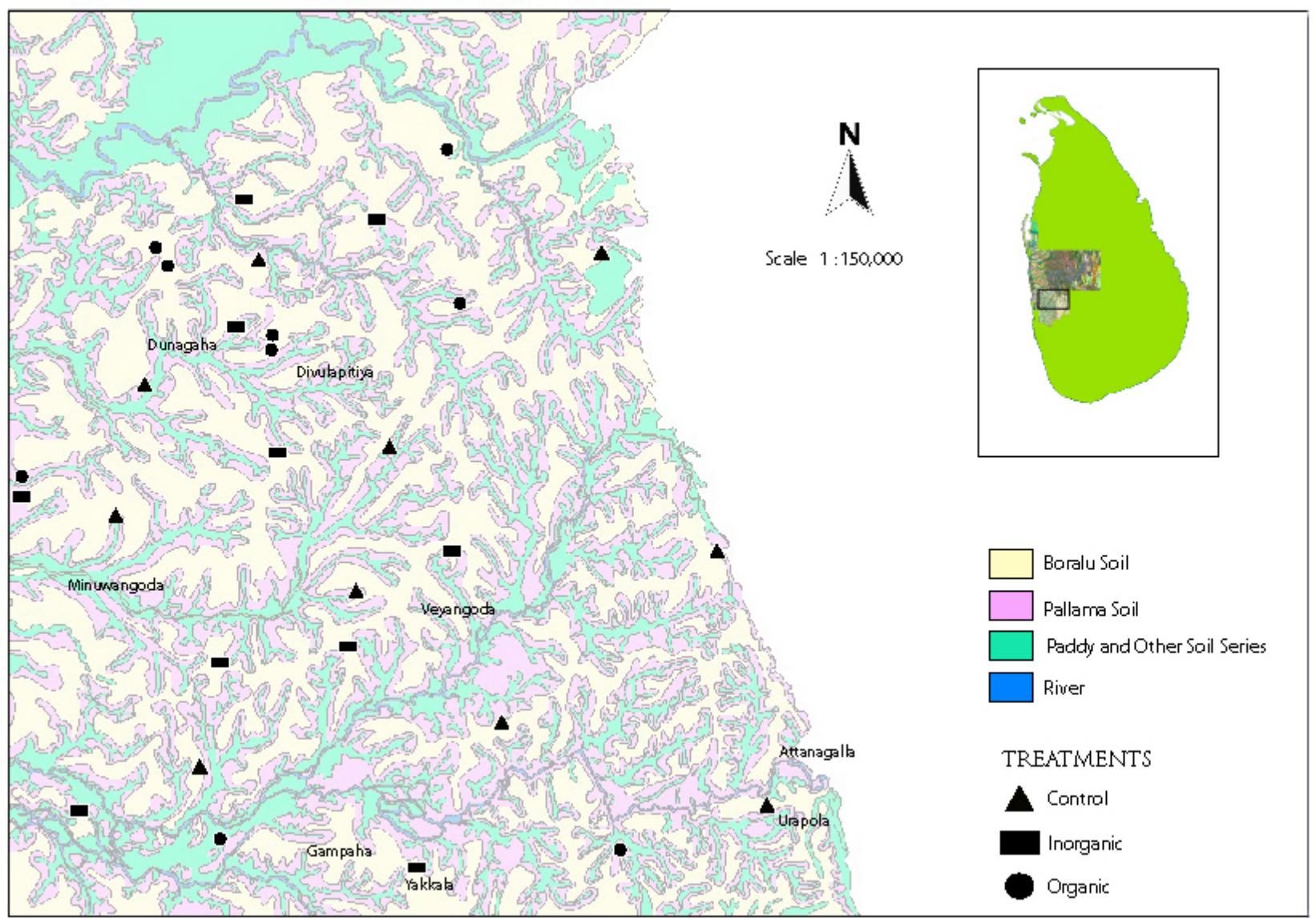

Figure01: SAMPLING LOCATIONS IN GAMPAHA AREA

\section{Collection of Leaf Samples}

Leaf samples to determine P-nutritional status were taken from coconut palms in the 10 sampling locations where inorganic fertilizers were applied. Leaflets arising from a $10 \mathrm{~cm}$ long mid portion of the $14^{\text {th }}$ frond, counting from the first fully opened frond, were taken for analysis. At each sampling location, samples were collected from four palms and bulked to give a composite sample to represent the location.

The leaf samples were first washed in running tap water, and then with distilled water three times and oven dried at $85^{\circ} \mathrm{C}$ for a maximum of 72 hours. The dried samples were powdered using a hammer mill with a stainless steel grinder and stored in polythene bags for chemical analysis. 


\section{Analysis of Soil Samples}

\section{Determination of Electrical Conductivity (EC)}

EC of the soil samples was determined in a 1:5 suspension of $10 \mathrm{~g}$ sieved (2mm), air dried soil in $50 \mathrm{ml}$ of distilled water. The soil suspension was stirred and left to equilibrate for 30 minutes. Then the EC was measured electrometrically, without disturbing the soil, using an Orion Research Model 145A plus EC meter (Tropical soil and leaf analytical methods, 1982).

\section{Determination of $\mathrm{pH}$ (1:5w/w water}

The soil suspensions used for measuring EC were stirred, and their $\mathrm{pH}$ values measured electrometrically using an Orion Research Model 410A plus $\mathrm{pH}$ meter after calibrating the instrument at $\mathrm{pH} 4$ and $\mathrm{pH} 7$ (Black 1965).

\section{Determination of available phosphorus}

Soil samples were ground again in a motor driven agate mortar and passed through a $0.15 \mathrm{~mm}$ (100 mesh) sieve. The available phosphorus in soil samples was extracted with the acid fluoride Bray and Kurtz No.1 method (Bray and Kurtz, 1945). The phosphorus concentrations were then measured colorimetrically using the spectrophotometer (CE 2030) at $660 \mathrm{~nm}$ wave length by the molybdenum blue colour method (Murphy and Riley, 1962).

\section{Analysis of Leaf Samples}

Leaf samples were digested with a 4:1 mixture of $\mathrm{HNO}_{3}$ and $\mathrm{HClO}_{4}$ acid and the contents of leaf phosphorus were determined using Auto AnalyzerTechnicon II (Tropical soil and leaf analytical methods, 1982).

\section{Data Analysis}

The data were analyzed using SAS/STAT Package (Anon, 1999). The analytical design used was Complete Randomized Design. 


\section{RESULTS AND DISCUSSION}

\section{Electrical Conductivity (EC)}

The electrical conductivity values of all the soils tested, across soil depths, field positions (MC and CS), fertilizer regimes and soil series, ranged widely from 20.2 to $155.6 \mu \mathrm{s} / \mathrm{cm}$ with a general mean of $62.66 \mu \mathrm{s} / \mathrm{cm}$ (Table 1). Nearly one-fifth (19.5\%) of the soils analyzed had an EC value of greater than $100 \mu \mathrm{s} / \mathrm{cm}$.

Top soils had a mean EC of $78.18 \pm 39.19 \mu \mathrm{s} / \mathrm{cm}$, which was significantly higher than of sub soils (mean of $47.14 \pm 24.14 \mu \mathrm{s} / \mathrm{cm}$ ). Generally, top soil is more fertile due to the addition of fertilizers and also mulch, which improves the soil organic matter status. As a result, the ion concentration in top soil is high.

EC of the soil in the manure circles (mean of $71.82 \pm 37.59 \mu \mathrm{s} / \mathrm{cm}$ ) was significantly higher than in the coconut square (mean of $53.13 \pm 31.79$ $\mu \mathrm{s} / \mathrm{cm}$ ) clearly, a direct result of applying fertilizers.

EC values of the soils of the different fertilizer regimes (No fertilizers, Inorganic fertilizer and Organic manure), and of the soil series (Boralu and Pallama), were not significantly different.

\section{Soil pH}

The $\mathrm{pH}$ of all the different soils tested ranged from 4.04 to 6.83 as shown in Table 2. The $\mathrm{pH}$ of the soils in the 'No fertilizer' regime (4.47) was significantly lower than in the inorganic fertilizer (5.48) and organic manure (5.09) regimes. The soil $\mathrm{pH}$ in the two latter regimes (inorganic fertilizer and organic manure) were not significantly different.

The $\mathrm{pH}$ of the soils from different field positions (MC and CS), or soil depths (top soil and subsoil) or soil series (Boralu and Pallama) were not significantly different. The soils collected from all sampling sites were within the favourable $\mathrm{pH}$ range for coconut cultivation (Pethiyagoda, 1980). 
Table 1. Electrical conductivity values (mean $\pm \mathrm{sd}$ ) of top soil and subsoil in the manure circle (MC) and the coconut square (CS), under different fertilizer regimes in coconut plantations in Boralu and Pallama soil series.

\begin{tabular}{|c|c|c|c|c|c|}
\hline \multirow{3}{*}{$\begin{array}{c}\text { Fertilizer } \\
\text { Practice }\end{array}$} & \multirow{3}{*}{ Position } & \multicolumn{4}{|c|}{ Electrical Conductivity (EC) ( $\mu \mathrm{s} / \mathrm{cm})$} \\
\hline & & \multicolumn{2}{|c|}{ Boralu soil series } & \multicolumn{2}{|c|}{ Pallama soil series } \\
\hline & & Top soil ${ }^{\mathrm{a}}$ & Sub soil $^{b}$ & Top soil ${ }^{\mathrm{a}}$ & Sub soil $^{b}$ \\
\hline \multirow[t]{2}{*}{ Organic } & $\mathrm{MC}$ & $\begin{array}{l}78.4 \pm 42.4 \\
(38.9-136)\end{array}$ & $\begin{array}{l}58.8 \pm 15.8 \\
(42.0-80.5)\end{array}$ & $\begin{array}{l}45.3 \pm 22.9 \\
(29.5-61.5)\end{array}$ & $\begin{array}{l}46.1 \pm 4.4 \\
(43.0-49.2)\end{array}$ \\
\hline & $\overline{C S}$ & $\begin{array}{l}62.6 \pm 20.9 \\
(32.8-81.5)\end{array}$ & $\begin{array}{l}40.2 \pm 10.7 \\
(24.2-53.5)\end{array}$ & $\begin{array}{c}93.9 \pm 39.0 \\
(58.6-136)\end{array}$ & $\begin{array}{l}27.7 \pm 9.4 \\
(20.4-38.3)\end{array}$ \\
\hline \multirow[t]{2}{*}{ Inorganic } & MC & $\begin{array}{l}80.5 \pm 18.9 \\
(52.6-101)\end{array}$ & $\begin{array}{l}58.4 \pm 31.4 \\
(20.7-104)\end{array}$ & $\begin{array}{l}90.4 \pm 53.2 \\
(31.9-156)\end{array}$ & $\begin{array}{l}47.6 \pm 10.3 \\
(34.9-60.5)\end{array}$ \\
\hline & $\mathrm{CS}$ & $\begin{array}{l}55.5 \pm 16.8 \\
(43.1-76.3)\end{array}$ & $\begin{array}{l}34.7 \pm 4.3 \\
(30.3-39.5)\end{array}$ & $\begin{array}{l}70.2 \pm 45.0 \\
(29.7-35)\end{array}$ & $\begin{array}{l}30.2 \pm 12.9 \\
(20.2-49.5)\end{array}$ \\
\hline \multirow[t]{2}{*}{ Control } & $\mathrm{MC}$ & $\begin{array}{l}126.9 \pm 43.6 \\
(49.8-151)\end{array}$ & $\begin{array}{l}80.6 \pm 40.6 \\
(52.8-149)\end{array}$ & $\begin{array}{l}66.4 \pm 32.7 \\
(41.6-112)\end{array}$ & $\begin{array}{l}42.1 \pm 11.6 \\
(31.6-58.8)\end{array}$ \\
\hline & CS & $\begin{array}{l}69.5 \pm 45.8 \\
(34.6-137)\end{array}$ & $\begin{array}{l}38.3 \pm 15.6 \\
(27.6-60.7)\end{array}$ & $\begin{array}{l}9.2 \pm 41.4 \\
(28.0-122)\end{array}$ & $\begin{array}{c}49.5 \pm 35.6 \\
(20.9-101)\end{array}$ \\
\hline
\end{tabular}

Range within parentheses. $\quad{ }^{\mathrm{a}}$ Top soil $=0-25 \mathrm{~cm} \quad{ }^{\mathrm{b}}$ Sub soil $=25-50 \mathrm{~cm}$ 
Table 2. Soil $\mathrm{pH}$ values (mean $\pm \mathrm{sd}$ ) of top soil and subsoil in the manure circle (MC) and the coconut square (CS) under different fertilizer regimes, in coconut plantations in Boralu and Pallama soil series.

\begin{tabular}{|c|c|c|c|c|c|}
\hline \multirow{3}{*}{$\begin{array}{c}\text { Fertilizer } \\
\text { Practice }\end{array}$} & \multirow{3}{*}{ Position } & \multicolumn{4}{|c|}{ Phosphorus (mg/kg) } \\
\hline & & \multicolumn{2}{|c|}{ Boralu soil series } & \multicolumn{2}{|c|}{ Pallama soil series } \\
\hline & & Top soil ${ }^{\mathrm{a}}$ & Sub soil $^{b}$ & Top soil $^{\mathrm{a}}$ & Sub soil $^{b}$ \\
\hline \multirow[t]{2}{*}{ Organic } & $\mathrm{MC}$ & $\begin{array}{l}48.5 \pm 20.2 \\
(24.0-72.1)\end{array}$ & $\begin{array}{l}52.0 \pm 31.1 \\
(23.0-98.4)\end{array}$ & $\begin{array}{l}27.5 \pm 3.4 \\
(25.1-29.8)\end{array}$ & $\begin{array}{l}12.5 \pm 1.1 \\
(11.7-13.3)\end{array}$ \\
\hline & CS & $\begin{array}{l}33.5 \pm 17.7 \\
(12.5-51.9)\end{array}$ & $\begin{array}{l}21.6 \pm 6.4 \\
(15-29.9)\end{array}$ & $\begin{array}{l}22.8 \pm 1.7 \\
(20.9-24.3)\end{array}$ & $\begin{array}{l}24.4 \pm 14.4 \\
(9.9-38.7)\end{array}$ \\
\hline \multirow[t]{2}{*}{ Inorganic } & $\mathrm{MC}$ & $\begin{array}{l}50.7 \pm 33.5 \\
(14.7-81.0)\end{array}$ & $\begin{array}{l}32.5 \pm 31.3 \\
(7.1-67.5)\end{array}$ & $\begin{array}{l}69.0 \pm 33.3 \\
(31.4-97.4)\end{array}$ & $\begin{array}{l}37.3 \pm 23.8 \\
(9.8-72.4)\end{array}$ \\
\hline & CS & $\begin{array}{l}23.8 \pm 5.0 \\
(17.2-29.8)\end{array}$ & $\begin{array}{l}13.9 \pm 5.1 \\
(9.2-20.7)\end{array}$ & $\begin{array}{l}20.9 \pm 9.9 \\
(6.5-31.6)\end{array}$ & $\begin{array}{l}18.9 \pm 3.9 \\
(12-21.8)\end{array}$ \\
\hline \multirow[t]{2}{*}{ Control } & MC & $\begin{array}{l}21.4 \pm 18.7 \\
(9.4-49.0)\end{array}$ & $\begin{array}{l}29.3 \pm 13.3 \\
(10.8-48.1)\end{array}$ & $\begin{array}{l}19.2 \pm 6.4 \\
(12.8-25.6)\end{array}$ & $\begin{array}{l}18.7 \pm 12.3 \\
(6.3-36.8)\end{array}$ \\
\hline & CS & $\begin{array}{l}11.4 \pm 4.5 \\
(4.8-14.2)\end{array}$ & $\begin{array}{l}13.1 \pm 10.9 \\
(6.2-25.6)\end{array}$ & $\begin{array}{l}17.1 \pm 13.7 \\
(4.5-31.8)\end{array}$ & $\begin{array}{l}7.0 \pm 1.7 \\
(4.6-9.1)\end{array}$ \\
\hline
\end{tabular}

$\mathrm{LSD}_{0.05}$ for fertilizer practice $=9.473$

Range within parentheses $\quad{ }^{\mathrm{a}}$ Top soil $=0-25 \mathrm{~cm}{ }^{\mathrm{b}}$ Sub soil $=25-50 \mathrm{~cm}$

\section{Available phosphorus}

The available phosphorus values of all the soils tested, across soil depths, field positions (MC and CS), fertilizer regimes and soil series, ranged widely from 48.5 to $7.0 \mathrm{mg} / \mathrm{kg}$, with a general mean of $22.5 \mathrm{mg} / \mathrm{kg}$ (Table 3).

Available phosphorus in the two major soil series Boralu and Pallama was highly variable. In tropical soils, $10 \mathrm{mg} / \mathrm{kg}$ available phosphorus is generally regarded as being sufficient (Brady, 1990). On this basis, the available phosphorous was at a sufficient level in $85 \%, 100 \%$ and $90 \%$ of the manure circles, and $35 \%, 90 \%$ and $85 \%$ of the coconut squares, in the no fertilizer, organic manure and inorganic fertilizer regimes, respectively. Available phosphorus in the different sampling locations are shown in Figure 2. 
The mean concentration of available phosphorus of the soils in the 'No fertilizer' regime $(20.63 \mathrm{mg} / \mathrm{kg})$ was significantly lower than in the inorganic fertilizer $(33.35 \mathrm{mg} / \mathrm{kg}$ ) and organic manure $(31.46 \mathrm{mg} / \mathrm{kg})$ regimes. Available phosphorus concentrations in the two latter regimes (inorganic fertilizer and organic manure) were not significantly different.

Available phosphorus concentration in the manure circles (48.5) was found to be significantly higher than in the centre of coconut squares (33.5). This could be ascribed to the residual effects of phosphorus fertilization over the past five years. Available nutrients are readily fixed on to the clay and organic fractions of the soil and are retained over long periods (Brady, 1990). For similar reasons, available phosphorus of top soil $(34.7 \mathrm{mg} / \mathrm{kg})$ was significantly higher than in sub soil $(22.7 \mathrm{mg} / \mathrm{kg})$. This is clearly related to the higher level of organic matter and clay content in the top soil. The surface retention of phosphate has also been reported in sandy soil, red yellow podzolic soil and some coconut soils ( Chang and Chu, 1961; Bromfield,1965; Loganathan and Balakrishnamurthi 1983;Amulu and Obigbesan, 1990).

Table 3. Available phosphorus (mean \pm sd) of top soil and subsoil in the manure circle (MC) and coconut squares (CS), under different fertilizer regimes, in coconut plantations in Boralu and Pallama soil series.

\begin{tabular}{|c|c|c|c|c|c|}
\hline \multirow{3}{*}{$\begin{array}{c}\text { Fertilizer } \\
\text { Practice }\end{array}$} & \multirow{3}{*}{ Position } & \multicolumn{4}{|c|}{ Phosphorus (mg/kg) } \\
\hline & & \multicolumn{2}{|c|}{ Boralu soil series } & \multicolumn{2}{|c|}{ Pallama soil series } \\
\hline & & Top soil ${ }^{\mathrm{a}}$ & Sub soil $^{\mathrm{b}}$ & Top soil ${ }^{\mathrm{a}}$ & Sub soil $^{b}$ \\
\hline \multirow[t]{2}{*}{ Organic } & MC & $\begin{array}{l}48.5 \pm 20.2 \\
(24.0-72.1)\end{array}$ & $\begin{array}{l}52.0 \pm 31.1 \\
(23.0-98.4)\end{array}$ & $\begin{array}{l}27.5 \pm 3.4 \\
(25.1-29.8)\end{array}$ & $\begin{array}{l}12.5 \pm 1.1 \\
(11.7-13.3)\end{array}$ \\
\hline & CS & $\begin{array}{l}33.5 \pm 17.7 \\
(12.5-51.9)\end{array}$ & $\begin{array}{l}21.6 \pm 6.4 \\
(15-29.9)\end{array}$ & $\begin{array}{l}22.8 \pm 1.7 \\
(20.9-24.3)\end{array}$ & $\begin{array}{l}24.4 \pm 14.4 \\
(9.9-38.7)\end{array}$ \\
\hline \multirow[t]{2}{*}{ Inorganic } & MC & $\begin{array}{l}50.7 \pm 33.5 \\
(14.7-81.0)\end{array}$ & $\begin{array}{l}32.5 \pm 31.3 \\
(7.1-67.5)\end{array}$ & $\begin{array}{l}69.0 \pm 33.3 \\
(31.4-97.4)\end{array}$ & $\begin{array}{l}37.3 \pm 23.8 \\
(9.8-72.4)\end{array}$ \\
\hline & CS & $\begin{array}{l}23.8 \pm 5.0 \\
(17.2-29.8)\end{array}$ & $\begin{array}{l}13.9 \pm 5.1 \\
(9.2-20.7)\end{array}$ & $\begin{array}{l}20.9 \pm 9.9 \\
(6.5-31.6)\end{array}$ & $\begin{array}{l}18.9 \pm 3.9 \\
(12-21.8)\end{array}$ \\
\hline \multirow[t]{2}{*}{ Control } & MC & $\begin{array}{l}21.4 \pm 18.7 \\
(9.4-49.0)\end{array}$ & $\begin{array}{l}29.3 \pm 13.3 \\
(10.8-48.1)\end{array}$ & $\begin{array}{l}19.2 \pm 6.4 \\
(12.8-25.6)\end{array}$ & $\begin{array}{l}18.7 \pm 12.3 \\
(6.3-36.8)\end{array}$ \\
\hline & CS & $\begin{array}{l}11.4 \pm 4.5 \\
(4.8-14.2)\end{array}$ & $\begin{array}{l}13.1 \pm 10.9 \\
(6.2-25.6)\end{array}$ & $\begin{array}{l}17.1 \pm 13.7 \\
(4.5-31.8)\end{array}$ & $\begin{array}{l}7.0 \pm 1.7 \\
(4.6-9.1)\end{array}$ \\
\hline
\end{tabular}




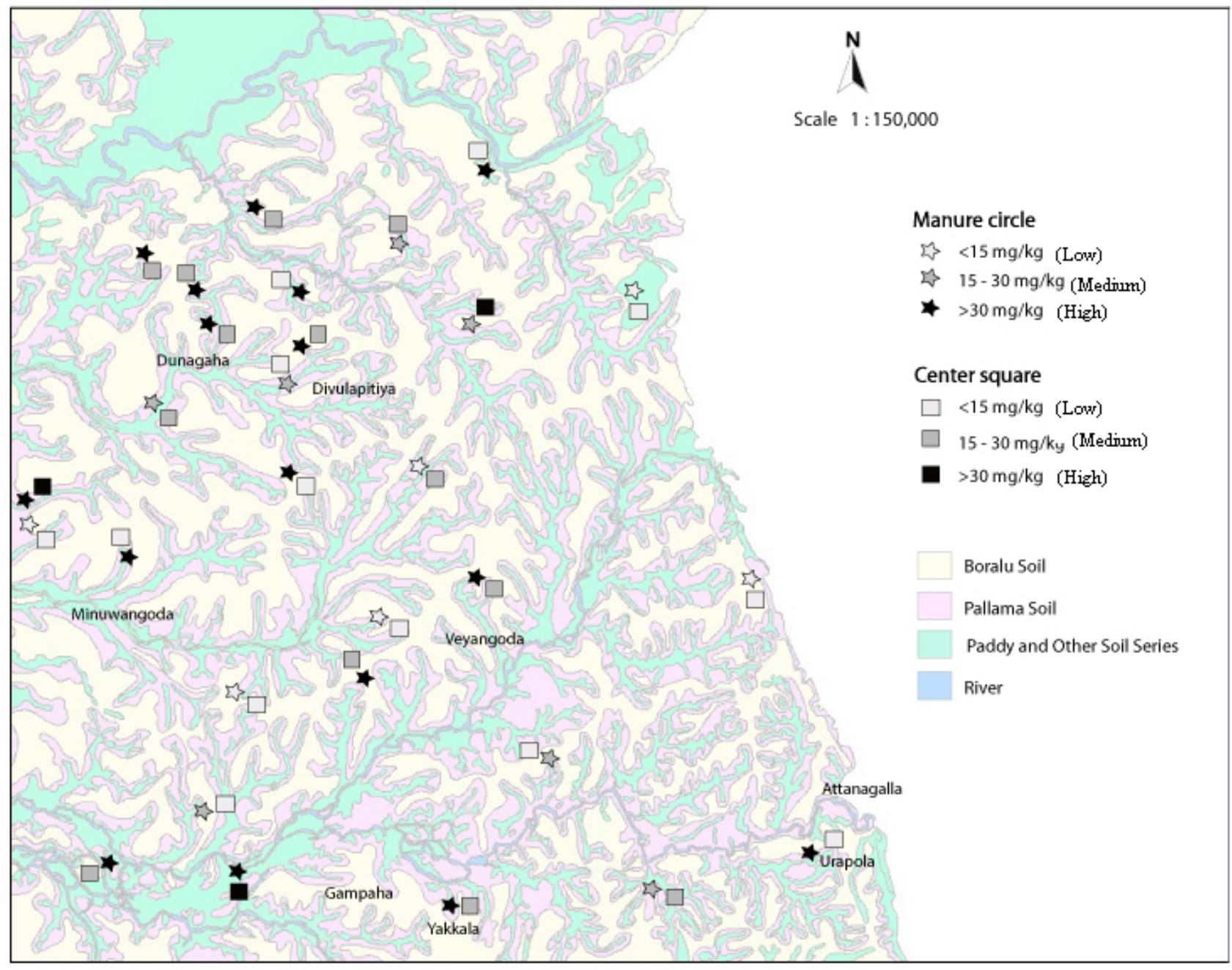

Figure 02 : AVAILABLE PHOSPHORUS OF SAMPLING LOCATIONS IN GAMPAHA AREA

$\mathrm{LSD}_{0.05}$ for fertilizer practice $=9.473$

Range within parentheses ${ }^{\mathrm{a}}$ Top soil $=0-25 \mathrm{~cm}$ bSub soil $=25-50 \mathrm{~cm}$

The available phosphorus in the centre of coconut squares of the 'No fertilizer' regime ranged from 4.8 to $31.8 \mathrm{mg} / \mathrm{kg}$, with a mean of $16 \mathrm{mg} / \mathrm{kg}$. Loganathan et. al., (1984) reported that Bray and Kurtz No.1 P ranged from 0.2 to $3.6 \mathrm{mg} / \mathrm{kg}$, with a mean of $1.3 \mathrm{mg} / \mathrm{kg}$, for unfertilized soils in Sri Lanka. The considerably high mean of $16 \mathrm{mg} / \mathrm{kg}$ recorded in the present study could be due to fertilizer applied before the five-year period of this experiment. The phosphorus source in coconut fertilizer mixtures is either Imported Rock Phosphate (IRP) or Eppawala Rock Phosphate (ERP), Both these fertilizers decompose slowly and release phosphorus to the soil over a long period. Wahid (1977) reported that the available P content of laterite 
soils of coconut-growing regions of India was $8.5 \mathrm{mg} / \mathrm{kg}$ (Bray and Kurtz No.1P method).

Soils with an extractable phosphorus content, determined by Bray and Kurtz No.1P method, of $15 \mathrm{mg} / \mathrm{kg}$ or less are categorized as 'low', and 16-30 $\mathrm{mg} / \mathrm{kg}$ as 'medium', in regard to phosphorus availability (Thomas and Peaslee, 1973). This categorization was not specifically for coconut or for soils of Sri Lanka. Nevertheless, it could serve as a guide in evaluating the phosphorus availability in the soils of Sri Lanka. Accordingly, available phosphorus content of Boralu and Pallama series soil in Gampaha District is, 'medium' in unfertilized lands; and 'high' (> $30 \mathrm{mg} / \mathrm{kg}$ ) in manure circle soils and 'medium' in the coconut square soils in fertilized lands (inorganic fertilizers or organic manures).

\section{Leaf phosphorus concentrations}

Leaf-P concentrations in the $14^{\text {th }}$ leaf at the ten sampling locations fertilized annually with inorganic fertilizer (APM), ranged from 0.135 to $0.196 \%$ (mean of $0.163 \%$ ) and 0.142 to $0.187 \%$ (mean of $0.162 \%$ ) in Boralu and Pallama soil series respectively (Table 4). These leaf-P concentrations are higher than the critical level of $0.120 \%$ (Fremond, et al.,1966; Kanapathy, 1971; Magat, 1979) and is in accordance with the medium to high levels of available phosphorus in the soil (Table 3).

Table 4. Leaf phosphorus concentration (mean \pm sd) in the $14^{\text {th }}$ leaf of coconut palms receiving inorganic fertilizers, in Boralu and Pallama soil series.

\begin{tabular}{lc}
\hline $\begin{array}{l}\text { Soil } \\
\text { series }\end{array}$ & Leaf phosphorus (\%) \\
\hline Boralu & $0.163 \pm 0.023$ \\
& $(0.135-0.196)$ \\
Pallama & $0.162 \pm 0.016$ \\
& $(0.142-0.187)$ \\
\hline
\end{tabular}

Range within parentheses.

Loganathan and Balakrishnamoorthi (1983), reported that leaf-P concentrations in the $14^{\text {th }}$ leaf of coconuts in 35 selected unfertilized sites, covering all coconut growing soils, ranged from 0.074 to $0.116 \%$. 


\section{Correlation of leaf phosphorus concentration with available phosphorus in soil.}

The correlation of leaf-P and available soil phosphorus extracted by Bray and Kurtz No.1P method was not significant. The correlation between leaf-P in $14^{\text {th }}$ frond and available $\mathrm{P}$ in the soils of the manure circle was negative $(\mathrm{r}=$ $-0.11, \mathrm{P}>0.05$ ). Nair (1979) reported that the critical nutrient levels in the leaf are dependent on a number of environmental and plant characters and they did not necessarily reflect the nutrient supplying capacity of the soil. The poor correlation implies that available soil phosphorus extracted by Bray and Kurtz No.1P method does not account for leaf-P concentrations of the coconut palm.

\section{CONCLUSION}

The two major soil series in the Gampaha District, Boralu and Pallama, were generally sufficient in available phosphorus for healthy growth of coconut. The leaf-P levels in the palms receiving annual applications of inorganic fertilizer was above the critical leaf-P concentration, confirming that the availability of soil phosphorus was sufficient. The lack of correlation between leaf phosphorus and available soil phosphorus showed that the Bray and Kurtz No.1 extractable phosphorus was not a suitable index of phosphorus availability.

\section{ACKNOWLEDGEMENTS}

Authors are grateful to Professor S.J.B.A. Jayasekara, Dean, Faculty of Agriculture and Plantation Management and Prof. N.E.M. Jayasekara, Head, Department of Plantation Management for their valuable suggestions. They also offer their profound gratitude to Dr. Sarath Peiris, Principal Statistician and Head of Biometry Division and Mr. S. Kularatne, Senior Technical Officer, Biometry Division, Coconut Research Institute, Lunuwila, for the great assistance in statistical analysis, and sincerely acknowledge the valuable assistance received from the staff of the Soils and Plant Nutrition Division, Coconut Research Institute, Lunuwila. A special word of thanks goes to the staff of the computer unit, Wayamba University, Makandura for providing computer facilities to prepare this paper. 


\section{REFERENCES}

Amulu, U.C. and G.D. Obigbesan. 1990. Studies on soils supporting coconut in southern Nigeria: Fertility status and its influence on coconut leaf nutrient composition. Nigerian Institute for Oil Palm Research Nigeria.11-17.

Anon 1999. SAS/STAT Software, Institute inc. Cary, NC 27513, USA.

Anon $^{\mathrm{a}}$ 2003. Annual Report of Central Bank of Sri Lanka, Colombo: 84.

Anon $^{\mathrm{b}}$ 2003. Plantation Sector Statistical Pocket book. Ministryof Plantation Industries, Vauxhall Lane, Colombo 02: 79.

Anon 1989. Annual Report of the Coconut Research Institute, Lunuwila, Sri Lanka.

Black, C.A. 1965. Methods of Soil Analysis Part 2.Chemical and Microbiological Properties. American Society of Agronomy.

Brady, N.C. 1990. The Nature and Properties of Soils. $\left(10^{\text {th }}\right.$ Ed.) Macmillan Publishing Company, New York.

Bray, R.H. \& L.T. Kurtz.1945. Determination of total, organic andavailable forms of phosphorus in soils. Soil science 69: 39-45.

Bromfield, S. M. 1965. Studies on the relative importance of $\mathrm{Fe}$ and $\mathrm{Al}$ in the sorption of phosphate by some Australian soils. Australian Journal of Soil Research 3: 31-44.

Chang, S.C., W.K. Chu. 1961. Fate of soluble phosphate applied to soil. Journal of Soil Science 12: 286-293.

Fremond, Y., R. Ziller and M. De Lamothe De Nuce. 1966. The Coconut Palm, Berne: International Potash Institute: 225.

Kanapathy, K, 1971. Preliminary work on foliar analysis as a guide to the manuring of coconut Malaysia. In Cocoa and coconut on Malaysia (ed. R. Westre and E.Earp), Kuala Lumpur Incorporated Society of Plants: 357-366. 
Loganathan, P. and T.S. Balakrishnamurti..1983. Fertilizer requirements of Adult Coconut Palms in Sri Lanka. In: Coconut Research and Development. (ed. N.M. Nayar). Wiley Eastern Limited, New Delhi. 127-135.

Loganathan, P., P.M.N. Dayaratne and R.T. Shanmuganathan. 1984. Evaluation of the Phosphorusstatus of some coconut growing soils of Sri Lanka Cocos 2: 29-43.

Magat, S.S. 1979.The use of leaf analysis in the conduct of coconut field fertilizer trials in the Philippines. The Philippines Journal of Coconut Studies 4: 32-38.

Murphy, J. and J. P. Riley.1962. A modified single solution method for the determination of phosphate in natural waters. Analysis of chemistry Acta, 27: 31-36.

Nair, P.K.R. 1979. Intensive multiple cropping with coconuts in India, Principles, Programmes, Prospects. Verlauy Paul Parcy Berlin and Hamburg: 147.

Pethiyagoda, U. 1980. Handbook on Coconut Cultivation. Coconut Research Institute, Lunuwila, Sri Lanka.

Thomas, G.W. and D.E. Peaslee, 1973. Testing soils for Phosphorus. In: Soil Testing and Plant Analysis (ed. L.M. Walsh and J. D. Beaton), Madison, Wisconsin: Soil science society of America Inc: 115-132.

Tropical soil and leaf analytical methods. 1982. Tropical analysis unit, U.K.

Wahid, P.A., C.B. Kamala Devi and M. Haridasan. 1977. A critical review of Phosphate fertilization of coconut. Philippine Journal of coconut studies 2: 1-7. 